\title{
Open defecation behavior of elementary school-aged children in the coastal region, Indonesia: A pilot study
}

\author{
Fadhilah Azzahra Hasan, Fausiah Ayuningsih, Warti Juraiti, and Faizah Sidiqah
}

Department of Environmental Health, Faculty of Public Health, Halu Oleo University, Sulawesi Tenggara, Indonesia

\author{
Doi: https://dx.doi.org/10.36685/phi.v7i3.437 \\ Received: 29 June 2021 | Revised: 12 August 2021 | Accepted: 1 September 2021 \\ Corresponding author: \\ Fadhilah Azzahra Hasan \\ Faculty of Public Health, Halu Oleo University \\ H.E.A. Mokodompit Anduonohu Street, Kendari, Sulawesi Tenggara, Indonesia \\ Email: fadhilahazzahra1@gmail.com
}

Copyright: (c) 2021 the author(s). This is an open-access article distributed under the terms of the Creative Commons Attribution Non-Commercial License, which permits unrestricted non-commercial use, distribution, and reproduction in any medium provided the original work is properly cited.

\section{Abstract}

Background: Open defecation is one of the public health problems. Such behavior will lead to contamination of water and food sources, which can cause several diseases, one of which is caused by polluted water (water-borne diseases).

Objective: This research aimed to describe open defecation behavior in elementary school-aged children in Kendari City, Indonesia.

Methods: This was a descriptive survey carried out on 11-12 June 2021 among 87 students. Open defecation behavior was seen from knowledge and attitude of open defecation and availability of latrines. Validated questionnaires were used to measure the variables. Descriptive statistics were used for data analysis.

Results: The results showed that the students lacked knowledge (42\%) and negative attitudes (44\%). In addition, $11 \%$ of the respondents did not have latrines; therefore, open defecation still exists.

Conclusion: The findings of this study indicated that most of the respondents had poor knowledge and attitude regarding the impact of open defecation on health. Therefore, the results can be used as the basic data to develop further research, and indeed, to inform public health workers to pay attention to this issue and health education related to open defecation behavior is highly needed.

Keywords: open defecation; school-age children; knowledge; attitude; practice; Indonesia

\section{Background}

One of the public health issues which remain a global problem is open defecation. Open defecation is one example of unhealthy behavior, which is defined as the act of processing dirt or feces in fields, forests, bushes, rivers, beaches, or other open places and spreading them to pollute the environment, soil, air, and water (Anggoro, 2017).
WHO 2010 data estimates that 1.1 billion people, or $17 \%$ of the world's population still practicing defecate outside, and $81 \%$ of the population in 10 countries in the world. Indonesia is the second-largest country in the world whose people practice open defecation after India. In 2016, 16.209.333 heads of families in Indonesia were still practicing open defecation of $67,453,504$ heads of families or $24.03 \%$ who were still defecated in the outside (Yulda et al., 2017). Nationally, the use of latrines in 2018 increased to 
75.16\% from $68.08 \%$ in 2017 and $63.86 \%$ in 2016 . Among 34 provinces in Indonesia, the Special Region of Yogyakarta had the highest latrine use rate in 2018, reaching 100\% (Paladiang et al., 2020)

Open defecation can directly or indirectly cause water and food sources contamination. This can cause several diseases, one caused by polluted water (water-borne diseases) (Tosepu, 2016; Anggoro, 2017). In addition, it will affect public health conditions with poor sanitation, personal hygiene, and the environment are associated with the spread of several infectious diseases, namely diarrheal disease, cholera, dysentery, and hookworm disease (Tosepu, 2019; Samosir \& Sitanggang, 2020).

Based on Decree of Minister of Health (Kepkemenkes) Number 852/Menkes/SK/IX/2008, which was later strengthened into Regulation of Minister of Health (Permenkes) Number 3 of 2014 that Community-Based Total Sanitation (STBM) was confirmed as a national strategy for sanitation development in Indonesia. STBM is one way to change sanitation and hygiene behavior through a community empowerment approach by triggering. In order to achieve this goal, the STBM implementation strategy focuses on creating an enabling environment, increasing the need for sanitation (demand creation), and increasing the provision of sanitation access (supply improvement) (Ministry of Health Republic of Indonesia, 2014)

Based on these problems, it is known that one of the open defecation causes in children is lack of knowledge and negative attitudes. Therefore, it is necessary to have health promotion to change the behavior of elementary school-aged children. This study aimed to provide an overview of defecation behavior in elementary school-age children.

\section{Methods}

\section{Study Design and Participants}

This study employed a descriptive survey design to describe the defecation behavior of school-age children. This research was conducted at Kendari Elementary School No 12, Bungkutoko Village, Abeli District, Indonesia, in June 2021. The samples were students from $3^{\text {rd }}$ to $6^{\text {th }}$ grade amounted to 87 students selected using total sampling.
Kendari Elementary School No 12 is located in Bungkutoko village, Abeli District, Kendari City, Indonesia, as one of the coastal areas in Indonesia. This island is \pm 1.58 - or $4 \%$ of Abeli District's area.

Most of the residents' livelihoods at Bungkutoko Village are fishermen, and only a small part of them are entrepreneurs/industrialists, employees, farmers, traders, etc. It illustrates that the population is still dependent on coastal and marine resources. The residents' livelihoods are mostly fishermen amounted to $64.43 \%$, and a small part of them was in the field of trained shamans amounted to $0.67 \%$. Only one public health center is available in Abeli Village. Many people experienced both infectious diseases or non-infectious diseases. Many people still do not pay attention to defecation behavior and healthy latrine facilities (Badan Pusat Statistik, 2021).

\section{Instruments}

The instrument of this research is a questionnaire adapted from the study results on the relationship between population characteristics and open defecation behavior in Kenongorejo Village, Pilangkenceng District, Madiun Regency (Adam, 2019). The questionnaire was used to measure knowledge, the attitude of open defecation, and the availability of latrines. The questionnaire was validated, with good validity and reliability (Adam, 2019)

\section{Data Analysis}

Frequency, percentage, pie charts, and narrative explanations were used to describe the findings.

\section{Results}

The results of this research indicated that the respondents' knowledge about defecation habits was not good $(42 \%)$, good (28\%), and enough $(30 \%)$. The most incorrect statements answered were the second statement (64\%), in which respondents thought that open defecation could not pollute the environment and clean water sources. Furthermore, in the third statement $(47 \%)$, the respondent considered that open defecation would not cause diarrhea. Besides, the fourth statement $(67 \%)$ in which the respondent considered that open defecation would not cause worm disease. 


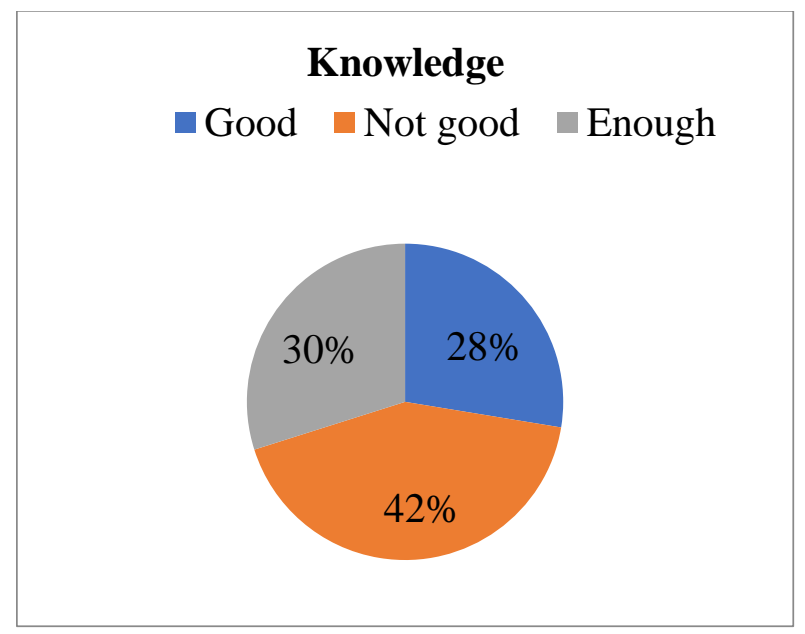

Figure 1 Results of knowledge regarding defecation habits

Based on the results of the study, attitudes towards bowel habits were negative (44\%), neutral $(30 \%)$, and positive (26\%). The statements that most agree with are statements number $2(60 \%)$ and number 3 $(66 \%)$. This means that respondents prefer to defecate in the latrine rather than in the sea, and they will warn people not to defecate in the open. The statements that most disagree with are statements number $1(34 \%)$ and number $4(37 \%)$. This means that if the respondent's food and drink are contaminated with feces, it cannot cause diarrhea, and if the respondent defecates openly, there will be no risk of transmitting diarrheal disease.

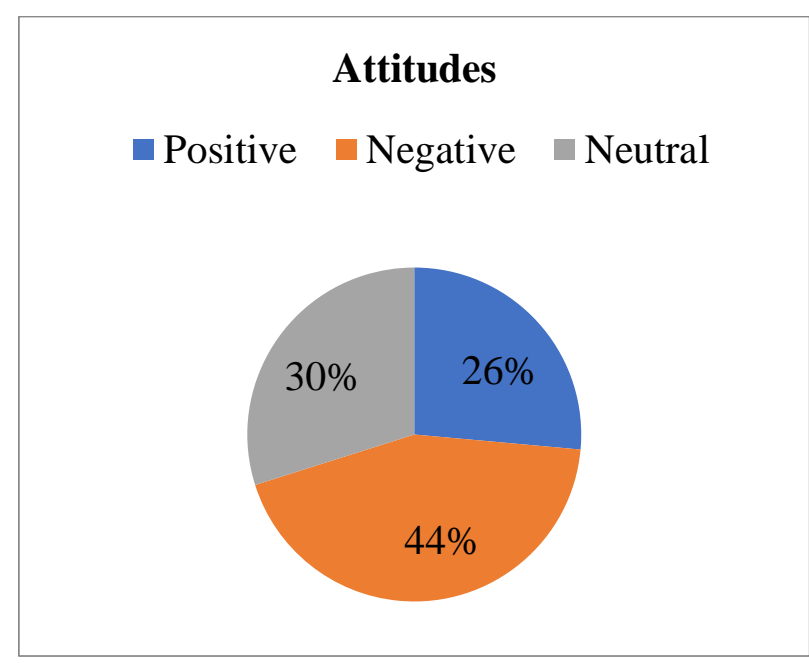

Figure 2 Results of Attitudes Regarding Defecation Habits

Based on the study results, $89 \%$ of respondents had a lavatory, and $11 \%$ did not. Many respondents already have latrines and use them, but ownership of healthy latrines consisting of containers/places for clean water, hand soap, and clean and running water was around $76 \%$.

\section{Latrine Availability}

Have a latrine Don't have a latrine

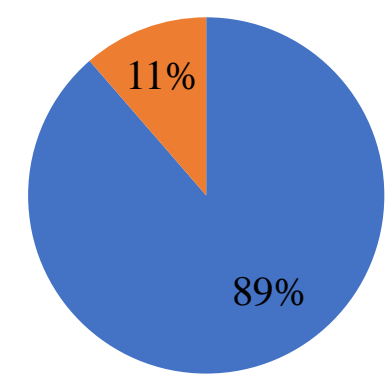

Figure 3 Results of Availability of Latrines at Home

\section{Discussion}

Based on several theories, behavior is formed or changed through three main things, namely intention, main skill to perform the behavior, and no obstacles in carrying out the behavior. The intentions can be influenced by five things, namely attitudes, social pressure, self-image, emotional reactions, and self-efficacy (Ajzen \& Madden, 1986; Theodorakis, 1994)

The conceptual framework for changing people's behavior to improve environmental hygiene and health is called the SaniFOAM concept. It is divided into five basic concepts: cleanliness, focus, opportunity, ability, and motivation. This concept is the basis of behavioral change factors. Knowledge is the study of knowledge or cognitive processes that focus on stimuli, especially individuals and groups, based on human perception of certain objects through the senses of sight, hearing, smell, taste, and touch (Febriani et al., 2016). Most of the human knowledge comes from seeing and hearing. Therefore, when people with good knowledge act based on their knowledge, they will perform better. A person's knowledge influences his actions or behavior. Referring to open defecation behavior in elementary school students, the basic knowledge that has to be possessed was the definition, the causes, and the impact of open defecation on health and environment, as well as positive attitude taken or carried out towards open defecation 
Behavior change must also be supported by high motivation. It can also be caused by internal factors, such as knowledge and relationships, and external factors, like family and social support. Family is considered the most comfortable place for individuals to share their problems, happiness, and hope for a better life. Eagly and Chaiken (1993) have suggested that support (incentives) is essential for people to change their behavior. The research results obtained that when respondents filled out the questionnaire, many of the families, especially the respondent's parents, refused to fill the questionnaire. This indicated that there was no support from family members in helping respondents changed their defecation behavior.

Based on the study results, it shows that respondents who had better knowledge about defecation had a better understanding than respondents who had less knowledge about defecation. Furthermore, respondents who had less knowledge assumed that open defecation could not pollute the environment or water sources and cause diarrhea and intestinal worms. This is because respondents did not know the negative impact of open defecation and could not find correct and clear sources about it.

The problem of human waste disposal is serious; hence it needs to be taken care of immediately because human waste (feces) is a source of disease transmission. This research found that respondents did not wash their hands with soap after defecating. This situation leads to different microorganisms live in the body, and it may cause diseases such as diarrhea which mostly happens to children. Once water, food, hands, and cutlery are contaminated with insects and feces, children will have diarrhea. Flies that eventually enter the feces and then enter the food can cause diarrhea-causing bacteria (Wahyuningsih, 2018). In this case, if the respondent does not defecate in the latrine, the respondent should immediately clean the feces and throw them into the restroom or bury it and washing hands with clean and running water. Clean and running water is a good source of water used for washing hands. Without washing hands properly can also cause diarrhea and intestinal parasites. These things are very helpful in improving health if it is done properly. Using the right technology and water sources is more effective at removing pathogens.
Hygiene and Healthy Behavior (PHBS) has added that washing hands should be done with clean, running water and use soap with some steps. The steps for washing hands is to wet hands with water, apply soap to the palms, lather hands by rubbing with the soap, stretch fingers alternately, thumb alternately, pads of fingers and wrists alternately, then rinse hand under running water and dry hands using a clean towel (Novianty et al., 2018). Many respondents answered questionnaires about the habit of washing hands that most of them washed hands with soap after defecating. This indicated good signs and understanding about defecating since washing hands is one of the ways to prevent the risk of various diseases. Even though the habit of washing hands properly has been carried out, it is also necessary to pay attention to the technique of washing hands for at least 20 seconds and using running water. The habit of washing hands properly is essential to prevent various diseases.

Attitude is a person's response to a stimulus or object that remains closed. Relationship performance cannot be seen directly; it can only be explained from closed behavior. Attitude actually connotes appropriateness in responding to certain stimuli. Attitude is a person's tendency or tendency to act or respond to positive and negative impulses from the object that is being stimulated (Suluwi \& Ismail, 2016)

Based on the results of this study, the respondent's attitude towards negative defecation (44\%), neutral $(30 \%)$, and positive (26\%). Many respondents agreed that respondents prefer to defecate in the toilet rather than the sea or river. This is in accordance with the theory of all port that the attitude consists of three main components: beliefs, which include ideas and concepts related to objects, human emotional lives or objects evaluations, and behavioral tendencies (Sulidah, 2016). In the overall relationship, mind, trust, and emotions play an important role in open defecation.

Notoatmojo's theory defines a person's attitude as a tendency to respond to environmental stimuli (a condition that is easily influenced), which can trigger or determine a person's (unfavorable) behavior towards certain people's objects or situations. In general, the relationship is closely related to knowledge (Notoatmodjo, 2010). When someone knows something very well, their attitude is usually 
positive (Febriani et al., 2016). The results of this study are in line with the statement of Notoatmodjo (2010), which states that an attitude is not necessarily realized or can be applied to an action. In an effort to realize an attitude, it is necessary to take action as evidence of real action, supporting factors, or enabling conditions are needed, one of which is the availability of latrines (Notoatmodjo, 2010).

According to (Priyoto, 2014), open defecation causes contamination of water, soil, air, food, and reproduction of flies. According to the ecological model, harsh environments can cause disease, namely: typhoid fever, parathyroid glands, dysentery, diarrhea, cholera, worms' disease, viral hepatitis, and various other digestive tract infections, as well as other parasitic infections. Efforts to prevent the spread of disease can be made by improving environmental hygiene. Accessibility of latrines is an effort to improve basic environmental hygiene and personal hygiene. This can break the chain of disease transmission (Muzaffar et al., 2020).

According to the research assumption, the availability of latrines is an important and serious matter in terms of habitual defecation behavior. Afterward, the Ministry of Health Republic of Indonesia (2014) stated that the availability of latrines also greatly influences defecation habits. Therefore, every house should have its own sanitary latrine according to established health standards. Based on the results, the latrine ownership of respondents was $89 \%$ compared to respondents who do not have a toilet. Although respondents already have latrines, the restrooms are not healthy, and there are still respondents who have lavatories but do not have septic tanks. This is in line with the research results of Rahmadani and Ridlo (2020) that all the people in Rangkah Village, Tambaksari District, defecated into the toilet. However, they did not have a septic tank; thus, they installed pipe from the latrine to the river, and the sewage in the latrine flows directly into the river. In addition, previous research conducted in Kaliwates District, Jember Regency, found that most people throw their feces directly into the river without prior management (Rahmadani \& Ridlo, 2020).

The limitation of this study was that this study was only descriptive in nature with a lack of samples, and therefore, cannot be generalized.

\section{Conclusion}

From this study, it can be concluded that the schoolage children had poor knowledge and attitude on the impact of open defecation behavior. Of $11 \%$ of unavailability of latrines is considered high, considering we are living in the modern era today. Therefore, the findings of this study can be used as the basic data to develop further research, and certainly, to inform public health workers to pay attention to this issue, and health education related to open defecation behavior is highly recommended.

Declaration of Conflicting Interest

The authors declare no conflict of interest.

Funding

None.

\section{Author Contributions}

Concept generation, data collection (Fadhilah Azzahra Hasan), writing and editing of the manuscript (Warti Juraiti, Faizah Sidiqah), critically reviewed, writing, and revision (Fausiah Ayuningsih).

\section{Author Biographies}

All authors are students of Department of Environmental Health, Faculty of Public Health, University of Halu Oleo, Indonesia.

\section{References}

Adam, S. P. (2019). Hubungan karakteristik penduduk dengan perilaku Buang Air Besar Sembarangan (BABS) Di Desa Kenongorejo Kecamatan Pilangkenceng Kabupaten Madiun. STIKES Bhakti Husada Mulia Madiun, Indonesia.

Ajzen, I., \& Madden, T. J. (1986). Prediction of goaldirected behavior: Attitudes, intentions, and perceived behavioral control. Journal of Experimental Social Psychology, 22(5), 453-474. https://doi.org/10.1016/ 0022-1031(86)90045-4

Anggoro, R. R. (2017). Gambaran perilaku buang air besar sembarangan pada masyarakat desa Jatimulyo, Kabupaten Bojonegoro. Jurnal Penelitian Kesehatan, 15(2), 129-134.

Badan Pusat Statistik. (2021). Kota Kendari dalam angka 2020. Jakarta: Badan Pusat Statistik

Eagly, A. H., \& Chaiken, S. (1993). The psychology of attitudes. California: Harcourt brace Jovanovich college publishers.

Febriani, W., Samino, S., \& Sari, N. (2016). Faktor yang mempengaruhi perubahan perilaku stop Buang Air Besar Sembarangan (BABS): Studi pada program 
STBM di Desa Sumbersari Metro Selatan 2016. Jurnal Dunia Kesmas, 5(3). https://doi.org/10.33024/ jdk.v5i3.467

Ministry of Health Republic of Indonesia. (2014). Kurikulum dan modul pelatihan Sanitasi Total Berbasis Masyarakat (STBM). Jakarta: Kementerian Kesehatan $\mathrm{RI}$.

Muzaffar, M., Elyarianti, E., \& Fitra, S. (2020). Hubungan pengetahuan masyarakat terhadap sikap dalam pencapaian target stop buang air besar sembarangan di Desa Mendale Kecamatan Kebayakan Kabupaten Aceh Tengah. Jurnal Serambi Akademica, 8(8), 16811687. https://doi.org/10.32672/jsa.v8i8.2727

Notoatmodjo, S. (2010). IImu perilaku kesehatan. Jakarta: Rineka Cipta

Novianty, S., Pasaribu, H. S., \& Pasaribu, A. P. (2018). Faktor risiko kejadian kecacingan pada anak usia pra sekolah. Journal of The Indonesian Medical Association, 68(2), 86-92. https://doi.org/10.47830/ jinma-vol.68.2-2018-91

Paladiang, R., Haryanto, J., \& Has, E. M. M. (2020). Determinan perilaku Buang Air Besar Sembarangan (BABS) di Desa Kiritana Kecamatan Kambera. Indonesian Journal of Community Health Nursing, 5(1), 33-40. http://dx.doi.org/10.20473/ijchn.v5i1.17 545

Priyoto. (2014). Teori perubahan perilaku dalam kesehatan. Yogyakarta: Nuha Medika

Rahmadani, R. D., \& Ridlo, I. A. (2020). Perilaku masyarakat dalam pembuangan tinja ke sungai di Kelurahan Rangkah, Surabaya. Jurnal PROMKES: The Indonesian Journal of Health Promotion and Health Education, 8(1), 87-98. http://dx.doi.org/10. 20473/jpk.V8.11.2020.87-98

Samosir, K., \& Sitanggang, H. D. (2020). Pemicuan jamban sehat sebagai solusi bebas buang air besar sembarangan pada masyarakat Kampung Bulang Kota Tanjungpinang. Jurnal Salam Sehat Masyarakat (JSSM), 2(1), 82-86.

Sulidah, S. (2016). Hubungan pengetahuan dan sikap masyarakat terkait kusta terhadap perlakuan diskriminasi pada penderita kusta. Medika Respati: Jurnal IImiah Kesehatan, 11(3).

Suluwi, S., \& Ismail, C. S. (2016). Pengaruh penyuluhan dengan metode permainan edukatif SUKATA terhadap pengetahuan, sikap dan tindakan tentang pencegahan penyakit cacingan pada siswa Kelas IV dan V SD Negeri 1 Mawasangka Kabupaten Buton Tengah tahun 2016. Jurnal Ilmiah Mahasiswa Kesehatan Masyarakat, 2(5), 1-10. http://dx.doi.org/ 10.37887/jimkesmas.v2i5.2092

Theodorakis, Y. (1994). Planned behavior, attitude strength, role identity, and the prediction of exercise behavior. The Sport Psychologist, 8(2), 149-165. https://doi.org/10.1123/tsp.8.2.149

Tosepu, R. (2016). Diseases in coastal communities in Indonesia: A review. Public Health of Indonesia, 2(3), 141-148. https://doi.org/10.36685/phi.v2i3.84

Tosepu, R. (2019). Public health significance of coastal communities. Public Health of Indonesia, 5(4), 145146. http://dx.doi.org/10.36685/phi.v5i4.322

Wahyuningsih, E. (2018). Pengaruh Perilaku keluarga terhadap kejadian diare pada balita Di Wilayah Kerja Puskesmas Jambu Kulon. MOTORIK Jurnal IImu Kesehatan, 13(2), 11-21.

Yulda, A., Fajar, N., \& Utama, F. (2017). Pengaruh faktor internal dan eksternal terhadap perilaku buang air besar di jamban pasca pemicuan di Wilayah Kerja Puskesmas Tanjung Batu. Jurnal IImu Kesehatan Masyarakat, 8(2). https://doi.org/10.26553/jikm.2016. 8.2.109-116 